\title{
Perceived Financial Adequacy in Old Age: A Case Study in Indonesia
}

\author{
Aris Ananta, b \\ Universitas Indonesia and Universiti Brunei Darussalam \\ Evi Nurvidya Arifin ${ }^{b}$ \\ Universiti Brunei Darussalam \\ Ahmad Irsan A. Moeis ${ }^{c}$ \\ Ministry of Finance, Republic of Indonesia
}

\begin{abstract}
Studies on perceived financial adequacy (PFA) among older persons are mostly about developed countries. However, the ageing population is undergoing an even faster rate in developing countries. This paper fills this gap, by examining economic-social factors associated with PFA in Indonesia, a developing country. The analysis uses statistics derived from three nationwide surveys conducted in 2015, enriched with insights on retirement income and retirement age derived from two online surveys, conducted in 2016/2017 and 2018. The result shows consistency in the pattern of objective income and PFA. This paper also finds that intensity of working and flexibility in working are positively associated with PFA. Better health and better living environment are positively associated with PFA. Finally, social assistance is negatively related to PFA. It reveals that older persons may not have been able to maintain the standard of living they had before retirement. Workers (future retirees) may want much higher retirement income and work longer as working is still the only reliable source of financial support in old age. It therefore recommends that the retirement age is raised, health is improved, decent living environment is enhanced, and the government continues with social assistance programmes.
\end{abstract}

Keywords: Ageing, employment, financial adequacy, health, retirement age, retirement income

JEL classification: I38, J14, J26

\section{Introduction}

Old age may mean deteriorating health, depreciating marketable skill, rising health expenditure, declining (or no) income. All of these can influence on how well the financial wellbeing in old age objectively or subjectively is. Together with actual income,

a Faculty of Economics and Business, Universitas Indonesia, Depok, West Java, Indonesia. Email: arisananta@ ui.ac.id (Corresponding author)

b Centre for Advanced Research (CARe), Universiti Brunei Darussalam, Jalan Tungku Link, Gadong, Brunei Darussalam. Email: evi.arifin@ubd.edu.bn

c Directorate General of Budget, Ministry of Finance, Republic of Indonesia, Gedung Sutikno Slamet, JI. Dr. Wahidin Raya No 1, Jakarta, Indonesia. Email: irsan.moeis@kemenkeu.go.id 
perceived financial adequacy is part of financial well-being (Litwin \& Sapir, 2009) and socio-health factors (Li et al., 1996; Litwin \& Sapir, 2009; Stoller \& Stoller, 2003). Based on a longitudinal study derived from 12 European countries, Litwin and Sapir (2009) found that perceived financial adequacy was confirmed as a valid measurement for economic status in old age. However, perception can matter more than an objective indicator in measuring financial wellbeing.

Not all individuals planned their financial situation at old age properly and are less likely to have adequate retirement (Reyers, 2018; Rappaport \& Bajtelsmit, 2019). Some may not even be able to make proper planning (Hanna et al., 2017). Planning for retirement financial adequacy is possibly worse in many developing countries than in developed countries (Reyers, 2018). It is thus important to evaluate older people's financial wellbeing in developing countries.

Moreover, studies on perceived financial adequacy were mostly on developed countries (Li et al., 1996; Stoller \& Stoller, 2003; Litwin \& Sapir, 2009). Presently, studies on perceived financial adequacy (PFA) among older persons carried out in low and middle-income countries (Gildner et al., 2016; Žiković, 2020) are still limited. It is therefore important to examine PFA in developing countries with less older people friendly infrastructure, lower income per capita and rapidly ageing population.

This paper fills the gap by focusing on Indonesia as a case of a middle-income country having the world's eighth largest older population, with fertility almost reaching replacement level. More specifically, using aggregate data from nationwide surveys, this paper examines a possible association between PFA and objective indicators of income; and seeks possible employment-health-social factors associated with PFA. It also provides insights on retirement income and retirement age based on data from two micro-studies, as an earlier study (Li et al., 1996) found that decision to retire can influence the adequacy of financial support in old age.

This paper begins with a literature review on factors associated with old-age financial wellbeing, the importance of perceived financial wellbeing, and the retirement system in Indonesia. Empirical results and discussion are then presented. Concluding remarks end the paper.

\section{Literature Review}

\subsection{Retirement Income Adequacy and Retirement Age}

Having daily routines and obtaining financial benefits were the most important considerations to work beyond retirement age (Sewdas et al., 2017). Some continued to work because of financial difficulties. From the state budget point of view, delaying retirement age may increase tax revenue (VanDerhei \& Copeland, 2011; Works, 2015). There is also a debate between health and retirement. A study in Singapore (Cheng \& Chan, 2018) found that retirement deteriorated health conditions, and working during retirement resulted in better health than being retired. On the other hand, a study in the United States (Works, 2015) found an endogeneity between health condition and retirement. Retirement may result in unfavourable health condition, but unfavourable health condition may result in retirement. However, Works' (2015) conclusion assumed that individuals can decide for themselves on their retirement ages. This can only be 
relevant for workers in informal sectors and without formal retirement planning as they have flexibility when to retire.

As people retire, the question is at what retirement financial adequacy people wish to retire. Rappaport and Bajtelsmit (2019) explained that retirement financial adequacy is supposed to maintain the living standard before retirement, be sufficient to manage future rising expenses, and be sure that it is at least above the poverty rate. Inflation rate should be taken into account in calculating future expenses. The consensus of retirement income adequacy among financial analysts is generally believed to be between $70 \%$ and $80 \%$ (Brady, 2010). However, from his simulation in the US, Brady showed a wider variation of retirement adequacy, depending on things such as accumulated savings and ownership of a house.

Brady also argued that retirement income should be lower than that of working years due to three reasons. First, retirement means no longer spending more for transportation, clothes and food than during working years. Second, during retirement, people use old durable goods bought many years ago. Third, retirees are free from financing their children. Thus, the retirement income adequacy can be $60 \%$, which cannot be applied for low income people, or the poor. The retirement adequacy of the poor can be $100 \%$ or even higher to alleviate them from poverty. Nevertheless, Brady's arguments may have missed to consider the importance of higher health expenditure in old age. In addition, durable goods will also eventually depreciate and need replacement. Furthermore, also with US data, Hanna et al. (2017) argued that people who expect to never retire may not be able to plan their retirement adequacy, instead they prefer to work indefinitely.

People in the US with career employment, having higher income, and/or multiple assets tend to have better prospects of retirement adequacy (Rappaport \& Bajtelsmit, 2019). However, people in the bottom income level obtained social safety net from social security, which forms a large percentage of their financial support. Unfortunately, the vulnerable groups (such as disabled, unemployed and widows) received less attention. In contrast, many workers in South Africa cannot save for the future (Reyers, 2018). With the defined contribution pension system, retirees only received $25 \%$ of preretirement income, far below the ratio discussed earlier. Therefore, older persons must continue to work and/or depend on assistance from the government, community and spouses/families.

Planning for retirement financial adequacy is related to the decision on what age to retire completely or partially (Li et al., 1996). In a defined benefit system, where the state can provide adequate pension, people may like to have younger retirement ages and, therefore, enjoy the benefits of pension earlier. On the other hand, in a defined contribution system, where people's pension is actually their own saving, people may like to delay the retirement age in order to increase their retirement benefits. People may withdraw the money earlier only if they believe they can better invest their money than the state does.

\subsection{Perceived Financial Adequacy}

Unfavourable economic conditions can be assessed subjectively and objectively in a dynamic interrelation through panel data (Ayllion \& Fusco, 2017). They argued that 
people may be above the poverty rate, as objective measure, but feel financially inadequate. They stated that receiving social assistance may increase the feeling of being financially inadequate. They found that past perceived financial difficulties may result in lower ability to earn income. A positive association between objective income and perceived income adequacy was observed by Grable et al. (2013). They also found a bias in individuals' estimation of their financial adequacy due to their financial satisfaction. People with less financial satisfaction evaluated their financial adequacy less than their objective income. However, they also found that perceived financial security may result in life satisfaction among older people.

Subjective wellbeing changes over lifespan. Perceived financial adequacy is asssociated with age but the relationship is not uniform among low and middle income countries (Gildner et al., 2016). López Ulloa et al. (2013) showed a U-shaped, inverted $\mathrm{U}$-shaped, or inelastic relationship between subjective wellbeing and age. Economists often argue that when it is a U-shaped, the minimum wellbeing occurs between ages 30 s and early 50s. This U-shape is seen in rich Western countries with good (defined benefit) pension system. People in those age bracket face obligations to their children and parents, as well as having their owned rising aspiration and competition in the job market. In contrast, people aged beyond 50 have more time to enjoy themselves.

This finding shows that being old is not necessarily gloomy. China and Russia are an example where people aged above 50 perceived more secure financially than younger people, Ghana and India are examples for an inverted U-shape, while South Africa and Mexico are examples for inelastic (Gildner et al., 2016). An inverted U-shape relationship is seldom observed. When it is observed, the peak of subjective wellbeing occurs between ages 50 and 65, when they are at the peak of their career. It assumes that income is positively related to subjective wellbeing. The flat relationship is often argued by psychologists who believe that individuals are born with certain characteristics and they are very adaptable to the changing environment, often called as hedonic adaptation. Furthermore, satisfaction can be transitory. Any satisfied situation creates another desire which creates unhappiness.

López Ulloa et al. (2013) also mentioned that gerontologists usually found that older people are happier. Subjective wellbeing does not seem to be affected by unfavourable conditions of being old. This result may be because of different cohorts, especially in the rapidly rising economies. The older people come from a generation with relatively lower economic conditions and therefore they are already happy with their conditions. They also concluded that the rising subjective wellbeing may stop at the oldest old. It starts declining among the oldest old.

\section{Retirement in Indonesia}

The formal retirement system in Indonesia is still limited and pension payout is meagre. For instance, a civil servant retiring at IV-b level receives at most 3.91 million rupiah monthly, slightly below the capital city (Jakarta) minimum monthly wage (3.94 million rupiah in 2019). Level IV is the highest level for a civil servant. The lowest is I-a with maximum monthly retirement payout at 1.76 million rupiah. A retiree with IV-e level, the highest within the IV level, receives a pension payout at most 4.43 million rupiah. 
It should be noted that Jakarta has the highest minimum wage among provinces in Indonesia. However, the criteria for monthly pension payout are the same regardless of where the retirees live. As a consequence, the retiree with IV-b level living in Jakarta has to live below the minimum wage; but a retiree with the same level can live more comfortably in the small city of Kuningan, province of West Java where the monthly minimum wage is 1.73 million rupiah in 2019 , much lower than Jakarta. ${ }^{1}$

The pension payout of a civil servant is calculated at $2.5 \%$ of last "basic" wage multiplied by years of working. The number of years working is at most 32 years. People who worked for more than 32 years do not get the credit for their work. Another limitation in getting payout is that the calculation of payout should not be more than $75 \%$ of last "basic" wage. ${ }^{2}$ Furthermore, this "basic" wage is usually only a small percentage of civil servants' monthly take-home income. Civil servants receive "allowance" and other additional income. Therefore, depending only on pensions, civil servants experience a drastic drop in their purchasing power and standard of living when they retire.

Therefore, in this country, labour force participation is almost a must to support individuals' life. However, labour participation declines as age increases resulting in declining income. With rising health costs but without any other sources of financial support, more Indonesian older persons will live in poverty and suffer from illness. This happens not only among the small percentage of Indonesians who formally retire but, as discussed earlier, also to most workers who are working without formal retirement planning. In a business-as-usual development planning, the rapid ageing population in a country like Indonesia will face a big challenge in taking care of its older persons.

\section{Data}

This paper empirically deals with two related issues. First is on the possible association between some socio-economic variables and perceived financial adequacy (PFA) among older persons. Second is on retirement age and income, both actual and desired. Two sets of data are used because there does not exist any data set which has all the information needed: financial adequacy at old age, variables likely to be associated with PFA, actual and desired retirement age, and actual and desired retirement income.

The first data set used to analyse the first issue was based on three nationwide surveys, covering agregregate data in all (34) provinces in Indonesia in 2015, which are available online. These surveys include the 2015 Intercensal Population Survey (SUPAS) as the latest nation-wide probabilistic survey collecting information on perceived

1 The data for pension is cited from "Peraturan Pemerintah Republik Indonesia Nomor 18 Tahun 2018" on "Penetapan Pensiun Pokok Pensiunan Pegawai Negeri Sipil dan Janda/Dudanya". The data for Jakarta minimum wage is cited from "Peraturan Gubernur Provinsi Daerah Khusus Ibukota Jakarta No. 114 Tahun 2018" on "Upah Minimum Provinsi Tahun 2018". The data for West Java minimum wage is cited from “Keputusan Gubernur Jawa Barat No. 56/kep 1220" on "Upah Minimum Kabupaten/Kota di Daerah Provinsi Jawa Barat Tahun 2019".

2 Based on "Peraturan Pemerintah RI No. 18 Tahun 2019" on "Penetapan Pensiun Pokok Pensiunan Pegawai Negeri Sipil dan Janda/Dudanya". 
financial adequacy among older people. ${ }^{3}$ Variables examined for possibility of having association with PFA are taken from 2015 SUPAS itself, and two other nation-wide surveys: 2015 National Labor Force Survey (SAKERNAS) and 2015 National Socioeconomic Survey (SUSENAS).

The 2015 SUPAS was conducted during 1 to 31 May 2015 and its sample were selected using stratified random sampling with 40,750 selected census blocks and about 652,000 selected households (Badan Pusat Statistik, 2015). PFA is specifically asked to older persons (aged 60 years and above) only. The question has a Yes-No response for "Apakah uang tersebut, cukup untuk memenuhi kebutuhan pribadi seharihari?" [Is the money you received sufficient to support your daily expenses?]. Other variables from SUPAS include percentage of older persons who did not have any health issues which disrupt their daily activities in the last one month and percentage of working older persons.

The other two surveys have a smaller number of selected households, 300,000 households for the SUSENAS conducted in March 2015 and 200,000 households for the SAKERNAS conducted in August 2015 (Badan Pusat Statistik, 2016). These two data sets provide more variables possibly associated with old-age financial wellbeing. From SUSENAS, the selected variables include income distribution of older persons measured by percentages of older persons in bottom $40 \%$ and top $20 \%$, percentage of older persons receiving cash subsidy for gasoline, percentage of older persons receiving assistance for rice, mean days of being sick, mean of monthly wage, mean of hours of weekly work, and percentage of older persons working in trade. From SAKERNAS, the selected variables include percentage of older persons having proper housing and percentage of abandoned (telantar) older persons.

However, these three surveys do not collect information on actual and desired retirement age as well as actual and desired retirement income. Therefore, this study also utilises a second data set, based on two non-probabilistic samples. The first sample is a survey from HSBC (2017) on desired retirement income and retirement age in 16 countries in the world, mostly in Asia, including Indonesia. The use of this data is to put the Indonesian case in the global context. The second sample is data from a pilot study (Moeis, 2018, supposed to extend the HSBC (2017) survey, concentrating on Indonesia).

The HSBC (2017) survey was conducted between November 2016 and January 2017 online with additional face-to-face interviews in Egypt and the United Arab Emirates (UAE), covering 18,414 persons in 16 countries and territories in Asia (eight countries/ territories, including Indonesia), Australia, South America (two countries), Europe (two countries), North America (two countries), and Africa (one country). The sample is made up of working-age population (21 years old and over) and retirees, permitting having information on perception among different generations.

Data on the pilot study (Moeis, 2018) was collected from 9 January to 2 February 2018 using a web-based online survey. Similar to the HSBC survey, the sample covered individuals aged 20 years old and over, including retirees. It has 2,468 respondents which are grouped into retirees, working population, non-working population, and students.

3 Another survey asking information on financial adequacy at old age is 2005 SUPAS. 
The respondents were relatively young with $88.94 \%$ aged between 20 and 50 years old. Most (73.49\%) of them were married, $24.01 \%$ were single; and $2.49 \%$ were no longer married. They were highly educated respondents, where $92.64 \%$ had earned diploma and university degrees with slightly more than half holding post-graduate degrees. More specifically, $39.14 \%$ of the sample had obtained a master degree while $2.82 \%$ had received a doctorate degree. This survey also included an urban bias with $72.73 \%$ of respondents being urban residents, which was higher than the urbanisation rate $(55.2 \%)$ of the country. This sample may represent future older persons in Indonesia, who will be more educated and urbanised.

\section{Empirical Results}

\subsection{Factors Associated with Perceived Financial Adequacy}

The 2015 SUPAS shows that a majority (78.5\%) of older Indonesians are perceived to be financially adequate. Similar to international variations (Gildner et al., 2019; Litwin \& Sapir, 2009), the data also shows provincial variation in perceived financial adequacy (PFA) among older persons, ranging from the lowest $(58.8 \%)$ in Bangka Belitung to the highest (89.2\%) in Bali. Furthermore, as shown in Sanjaya (2016), there has been an improvement in perceived financial adequacy (PFA) at old age from 73.3\% in 2005.

The variables associated with PFA are grouped into five clusters: income, employment, health, living environment and social assistance. Income cluster contains overall poverty rate, monthly salary of older persons, income distribution of older persons and non-labour income (interest from savings and/or stocks) of older persons. Employment cluster consists of percentage of working older persons, number of weekly working hours, working as self-employed and working in trade sector. Health cluster consists of percentage of older persons whose daily activities are not disrupted by health issues and the average days of older persons being sick in a month. Living environment contains percentage of older persons living in proper housing and percentage of abandoned older persons. Social assistance cluster includes percentage of older persons receiving cash subsidy for gasoline and percentage of older persons receiving rice assistance.

\section{Income Cluster}

In 2015, working older persons in Indonesia earned lower monthly salary/wage than the youngest workers aged 15-29 years old. The mean of monthly income of the young old (60-64) is $99 \%$ of the youth's (15-29) income, or $68 \%$ of monthly income of workers aged $45-59$. In addition, the monthly salary of people aged $60-64$ is about $79 \%$ of the 2015 national minimum wage. On average, the older persons earned 1.2 million rupiah (US\$85) per month, or $66 \%$ of the national minimum wage. Therefore, older persons earn poor wages. However, there exists provincial differences in monthly income and minimum wage. The mean of monthly income widely varies among provinces, ranging from as low as 0.74 million rupiah in East Nusa Tenggara or 0.59 of its 2015 regional minimum wage to as high as 3.79 million rupiah in Jakarta or 1.4 times of its 2015 regional minimum wage. 
On the other hand, the provincial pattern of PFA has a positive association with objective indicators of income, supporting Grable et al. (2013) and Ayllion and Fusco (2017) on the consistency between objective and subjective indicators of old-age financial wellbeing.

First, poverty rate for the whole population is negatively associated with PFA. Furthermore, there is also a negative association between percentage of older persons having monthly wages less than 500 thousand rupiah (US\$35) and PFA. A province with a higher poverty rate, measured for both the whole population and among the older persons themselves, is likely to be a province with low PFA. Second, income distribution is positively related to PFA, as shown by the negative association between percentage of the bottom $40 \%$ and PFA, and positive association between the percentage of the top $20 \%$ and PFA. A province with a better income distribution is likely to be a province with higher PFA. Third, mean of monthly income is positively associated with PFA. Moreover, non-labour income is also positively associated with PFA.

However, a different picture is seen in some provinces. There are eight provinces (West Nusa Tenggara, Central Java, West Sulawesi, Gorontalo, South Sulawesi, East Java, Southeast Sulawesi, and Lampung) with more than half of older persons belonging to the bottom $40 \%$ or more than $40 \%$ having monthly income less than 500 thousand rupiah (about US\$0.35), but $80 \%$ of them perceived having financial adequacy. In Yogyakarta, $48.8 \%$ older persons belong to the bottom $40 \%$ and yet $85.5 \%$ perceived having adequate income. Yogyakarta's PFA is higher than in all eight mentioned provinces. This supports the discussion by Grable et al. (2013) and Stoller and Stoller (2003), who showed that financial adequacy may be related to people's satisfaction. Older persons in these eight provinces may be happy with what they already have, though they have low income. On the other spectrum, four provinces (Riau Islands, East Kalimantan, North Kalimantan and Jakarta) having lower than $10 \%$ of poverty among older persons, measured by monthly income less than 500 thousand rupiah, showed a very high PFA (above 83\%).

\section{Employment Cluster}

This study finds that whether or not an older person is working is not significantly associated with PFA. Rather, the number of weekly hours at work is positively associated with PFA; percentage of older persons working as self-employed has an inverted U-curve relationship with PFA with the peak at $67.0 \%$; and percentage of older persons working in the trade sector is positively associated with PFA.

Though working or not is associated with PFA, the 2015 SUPAS data showed that almost half $(46.5 \%)$ of older persons were still working. The percentage varied among provinces, ranging from the highest $(57.8 \%)$ in East Nusa Tenggara to the lowest $(29.8 \%)$ in Jakarta. As discussed in Arifin and Ananta (2009), in the absence of generous social security and disappearing family support, not working at old age is a luxury. The data also indicated that the percentage of working older persons have a declining trend against age, from $60.0 \%$ for ages $60-64$, declining to $50.9 \%$ for ages $65-69,37.8 \%$ for ages $70-74,27.8 \%$ for ages $75-79$, and $16.6 \%$ among the oldest old (80 years old and over). This declining pattern might reflect worsening health, depreciating marketable skill, or norms and regulations against working older persons. 
Number of working hours seems to be significantly and positively associated with PFA. Older persons in Indonesia remained working long hours. Most worked 15-35 hours a week $(42.82 \%)$ and $>35$ hours a week $(42.52 \%)$. Those in urban areas worked longer hours: $52.82 \%$ worked longer than 35 hours and $35.39 \%$ worked $15-35$ hours. Looking at the sex pattern reveals that more male older persons worked $>35$ hours $(48.14 \%)$ than female older persons (32.70\%). On the other hand, more female older persons worked $15-35$ hours a week $(47.44 \%)$ than male older persons $(40.14 \%)$. The long hours of working indicate that the older persons are still active and enjoing themselves or they are forced to work to sustain their life. The positive correlation between number of hours worked and PFA may indicate that they work longer to sustain their expenditure.

Furthermore, the majority (66.5\%) of working older persons are self-employed, whether or not working with assistants; and with $58.5 \%$ working in the agricultural sector (Badan Pusat Statistik, 2016). Therefore, they work mostly in the informal sector. Another employment variable significantly associated with PFA is working in trade. In 2015 , working older persons in trade consists of $19.70 \%$ of all working older persons, not much lower than $22.63 \%$ among the population of $15-59$ years old. In the urban area, the percentage of working older persons in trade is much higher (33.41\%) than in the rural area (9.67\%). The preference for working in trade may indicate their choice for more flexible jobs.

This finding is consistent with the study by Arifin and Ananta (2009) for cases in Southeast Asia, as older persons are likely to choose flexible jobs having less physical activity. They also have the flexibility in deciding when to retire and how much income they can earn. This further suggests that older persons may be forced to work due to poverty. The inverted U-curve relationship with PFA indicates that the percentage of self-employed is higher than $67.0 \%$, while a province with a higher percentage of selfemployed older persons is more likely to have lower PFA.

\section{Health Cluster}

This study finds two significant health variables. First is the variable indicating the percentage of older persons whose daily activities were not disrupted by health issues in the last one month.

This variable has a positive association with PFA. That is, a province with a higher percentage of older persons having no disruption in daily activities because of health issues is more likely to be a province with higher PFA. In 2015, the percentage of older persons having no disruption is $52.8 \%$, ranging from $35.5 \%$ in the Province of Central Sulawesi to $61.6 \%$ in the Province of Yogyakarta.

Consistently, the variable on number of days being sick is negatively associated with PFA. A province with higher number of days is more likely to be a province with lower PFA. In 2015, most older persons (71.49\%) were sick for between one and seven days. This percentage is similar for male and female, and urban and rural. In average, older persons are sick for 9.02 days, with a small variation among provinces, from $7.19 \%$ in North Kalimantan to $19.97 \%$ in North Sumatera.

Previous studies discussed earlier show possible association between retirement and unfavourable health. Cheng and Chan (2018) showed that retirement in Singapore 
is more likely to deteriorate the health condition of older persons. Works (2015) indicated that health and retirement have a two-way direction in the US. Deteriorating health may result in retirement or retirement results in deteriorating health.

This study concludes the importance of better health in higher PFA. Higher retirement age may then be associated with better health and higher PFA.

\section{Living Environment Cluster}

Two significant variables associated with PFA are found in this cluster: percentage of abandoned older persons and percentage of older persons having proper housing. A province with lower percentage of older persons or a higher percentage of older persons living in proper houses is more likely to have higher PFA.

To determine whether an older person is abandoned, the Statistics Indonesia uses the following seven criteria: attaining education of less than primary school; having main food $<14$ times a week; consuming plant-based food less than 4 times a week, eating meat less than twice a week, or the combination of plant-based food and meat less than 4.2 times a week; having proper clothes for <4 sets; no fixed place to sleep; no treatment when being sick; and working more than 35 hours a week. If the older person fulfils one criterion, then he/she is not abandoned. If the older person fulfils two criteria, then he/she is almost abandoned. If the older person fulfils more than two criteria, then he/she is abandoned. ${ }^{4}$

A house is considered as inappropriate if it fulfils two of the following seven criteria: per capita area $<7.2 \mathrm{~m}^{2}$, house roof made from leaves, house walls from bamboo, floor from soil, absence of toilet facilities, no-electricity source of light, distance of source of drinking water and septic tank $<10 \mathrm{~m}$.

Nationally, in 2015 , the abandoned older persons constitute $9.55 \%$ of older persons in Indonesia. The percentage ranges from the lowest $(2.27 \%)$ in the province of East Kalimantan to the highest $(24.44 \%)$ in the province of Papua. The percentage is higher in rural areas $(11.93 \%)$ than in urban areas $(6.84 \%)$. The percentage among male older persons is $10.15 \%$, somewhat higher than among female older persons $(9.03 \%)$. As expected, the percentage of abandoned older persons is negatively related with PFA. A province with a higher percentage of abandoned older persons is more likely to have lower PFA.

On the other hand, percentage of older persons with proper housing is positively related to PFA, that is, percentage of living in a proper house goes hand in hand with higher PFA. In 2015, a low percentage (3.24\%) of older persons live in inappropriate housing; a high percentage $(86.30 \%)$ lived in proper housing, and the rest $(10.45 \%)$ in almost inappropriate housing. The percentage of older persons living in inappropriate houses varies from the lowest $(0.32 \%)$ in Jakarta to the highest $(26.62 \%)$ in the Province of East Nusa Tenggara. The percentage is much higher in rural areas (5.36\%) than in urban areas $(0.85 \%)$. However, difference by sex is small, $3.18 \%$ among male and $3.32 \%$ among female.

4 It should be noted however, that these criteria may need a revision. People who work longer than 35 hours a week may or may not be poor. People who do not eat any meat may do so because they choose to eat plant-based food only. Some people also have on average only two meals a day. 
Social Assistance Cluster

In 2015, about half (50.34\%) of older persons receive rice assistance for the poor. The provincial difference is very wide, from $10.90 \%$ in Province of Jakarta to $80.07 \%$ in Province of West Nusa Tenggara. The percentage is higher in rural areas (60.03\%) than in urban areas (39.39\%).

Almost a quarter (23.54\%) of older persons received assistance in the form of fuel subsidy, also higher in rural areas (29.24\%) than in urban areas (17.10\%). The provincial percentage varies from $6.78 \%$ in Province of Jakarta to $42.38 \%$ in Province of West Papua.

Social assistance, measured with cash transfer for fuel subsidy or rice for the poor, is negatively associated with PFA. A province with higher social assistance is more likely to be with lower PFA. The associations between the percentages of these two social assistance and PFA are negative, indicating that those who have lower PFA are targets of social assistance. As indicated in an earlier study (Ayllion \& Fusco, 2017), receiving social assistance may lower the recipient's perception of financial adequacy.

\subsection{Desired and Actual Retirement Income Age}

Data from HSBC (2017) shows that Asians are more likely than Europeans to defer their retirement ages by at least two years to improve their retirement income. High percentages of working age population desiring higher retirement ages are seen in India (82\%), Hong Kong (80\%), Singapore (79\%), Taiwan (79\%), and Indonesia (79\%). This is in contrast to France (37\%) and UK (55\%).

One reason is perhaps that Europeans enjoy generous pension from the state through defined benefit systems, while Asians have defined contribution systems. Even if Asians have defined benefit systems, the coverage is still limited and the pension payout is too little. One exception is Japan which has a defined benefit system with generous pension and wide coverage. However, as reported in Harding (2018), the Japanese Prime Minister vowed to raise the retirement age from 65 to 70 and people may even defer their retirement after 70 .

On the other hand, as shown by Feng et al. (2019), the welfare state of China faces political complications to raise retirement ages. It plans to raise from 60 for male, 55 for female professional, and 50 for other female to three different scenarios: increased by 5 years for each of the mentioned groups, increased to 65 for male and 60 for female, or increased to 65 for both male and female. Old-age pensions have been seen by the people as a moral commitment by the government.

The HSBC survey also showed that the baby boomer generation, generation $X$ and Millennials have the same length of retirement years, but different entries and exits. The baby boomers have expected higher ages of retirement age and death. They are expected to retire at age 64 and die at age 84 . The generation X (born in 19661979) are expected to retire younger, at age 61 and die younger too, at age 81 . The Millennials are expected to retire even much earlier, at age 59 and die much younger, at age 79 (HSBC, 2017).

The HSBC data also indicated that Indonesia is one of the countries with the highest expected retirement years, more than 20 years. The difference is at the exit and 
entry ages. Argentines are expected to retire at age 63 and die at 86 . Singaporeans are expected to retire at 62 and die at 85 . However, Indonesians are expected to retire at 59 and die at 80 . Likewise, the Chinese are expected to retire at age 59 , but die at an older age, 85. Egyptians are an extreme, with only 4 years difference between expected retirement age (59) and death age (63).

Based on data from the pilot study (Moeis, 2018) as shown in Table 1, the most (between $85.0 \%$ and $90.0 \%$ ) out of three groups of respondents (retirees, working persons, students) desire to retire at age 51-60 and 61-79, with higher percentages desiring to retire at 51-60. This desired retirement age may reflect Indonesia's official retirement ages, which is mostly in the late 50 s for civil servants, military and police. Some are extended to their early 60s. In universities, lecturers with doctorate degree can retire at age 65 , and professors at age 70 with a possibility of being rehired. Generally, it is not mandatory for the private sector to follow the government rule for retirement age.

Table 1. Desired retirement ages by four working status (percentage)

\begin{tabular}{|c|c|c|c|c|c|c|c|}
\hline & \multicolumn{5}{|c|}{ Ages } & \multicolumn{2}{|c|}{ Total } \\
\hline & $<40$ & $41-50$ & $51-60$ & $61-70$ & $70+$ & $\%$ & $\mathrm{n}$ \\
\hline Retirees & 2.67 & 2.67 & 45.33 & 44.00 & 5.33 & 100.00 & 75 \\
\hline Working & 1.09 & 5.99 & 60.20 & 26.88 & 5.84 & 100.00 & 2020 \\
\hline Students & 1.67 & 6.32 & 61.30 & 25.18 & 5.75 & 100.22 & 300 \\
\hline Not Working & 7.69 & 20.88 & 52.75 & 12.09 & 6.59 & 100.00 & 300 \\
\hline
\end{tabular}

Source: Calculated from Moeis (2018).

The fourth group of respondents (non-working persons) has a different pattern. The percentage desiring to retire at $51-60$ or $61-70$ is smaller, only $64.84 \%$. On the other hand, the percentage of desiring to retire at younger ages ( $<50$ years old) is relatively large $(28.57 \%)$, compared to below $10.0 \%$ in each of the other three groups. It is not clear whether they have sufficient family support or their own savings (wealth) to finance the retiring period at young ages, given that they are not working during the interview. It should be noted that there is no unemployment benefit from the government of Indonesia.

The phenomena of desiring to retire at young ages, though only at small percentages, are worth noting. Among the retirees, it is mostly observed among those who actually retired before 50 years old. Thus, the desire may just reflect what has actually happened. Among workers, desiring to retire at young ages is observed among the young too ( $<50$ years old). The students are mostly young.

\subsection{Retirement Income: Actual and Desired}

Data from HSBC (2017) indicated that the global working-age population is pessimistic on the role of the state to protect them financially when they retire. The data shows that $65 \%$ of them did not believe (generous) pension system will exist when they retire. 
Furthermore, the Millennials (born in 1980-1997) are more pessimistic: $24 \%$ of them even believed that state pension will no longer exist when they retire. This is in contrast to the baby-boomers (born in 1945-1965), with only $17 \%$ of them believing that state pension will stop to exist.

Indonesia's situation is worse, there is no generous pension. Older people (aged 60 and over) rely on either family transfer or on their own (by working). For the younger age (60-64), half of them depend on their own, and $39.30 \%$ rely on family transfer. As they become older, the reliance on their own effort declines and the reliance on family transfer increases. However, in whatever the age group, transfer from the government is small, with a maximum at $11.56 \%$ of their total financial support. Non-labour income constitutes a tiny percentage (less than $2 \%$ ) of financial support. In other words, though older persons depend on their own income to support their life, they cannot rely on their own income as they become older (see Table 2).

Table 2. Indonesia: Sources of older persons' financial support by age, 2015

\begin{tabular}{lccccc}
\hline Age groups & $\begin{array}{c}\text { Labour } \\
\text { income }\end{array}$ & $\begin{array}{c}\text { Non Labour } \\
\text { income }\end{array}$ & $\begin{array}{c}\text { Govt. transfer } \\
\text { payment }\end{array}$ & $\begin{array}{c}\text { Family transfer } \\
\text { payment }\end{array}$ & Total \\
\hline $60-64$ & 50.76 & 1.42 & 8.52 & 39.30 & 100 \\
$65-69$ & 41.16 & 1.48 & 9.83 & 47.53 & 100 \\
$70-74$ & 30.05 & 1.58 & 10.81 & 57.56 & 100 \\
$75-79$ & 21.54 & 1.62 & 11.56 & 65.28 & 100 \\
$80+$ & 12.27 & 1.73 & 10.41 & 75.59 & 100 \\
\hline $\mathbf{6 0 +}$ & $\mathbf{3 8 . 1 2}$ & $\mathbf{1 . 4 6}$ & $\mathbf{9 . 7 4}$ & $\mathbf{5 0 . 6 8}$ & $\mathbf{1 0 0}$ \\
\hline
\end{tabular}

Note: Non-labour income consists of earning from saving and stocks.

Source: Calculated based on Badan Pusat Statistik (2015).

In terms of retirement income, the question is whether people will have adequate income when they retire. A survey by HSBC (2017) on working age population showed that only $34 \%$ of the global working population is expected to have retirement financial adequacy. A large majority (70\%) of them wanted to defer their retirement by at least 2 years. At the same time, $57 \%$ expected that technology will help them financially during their retirement age. Technology will help them to be connected with family and friends $(87 \%)$, in working (78\%), staying mobile and active (76\%), and monitoring and maintaining their health (73\%).

The HSBC data shows that India and Indonesia have the highest percentages of working age population who believed that they will have retirement financial adequacy (69\% and $61 \%$, respectively). The data also shows that Millennials are the most uncomfortable generation to face retirement age. In contrast, the baby boomers are the most comfortable with $42 \%$ of them believing they will have retirement financial adequacy versus $14 \%$ of the Millennials who perceived that they will have retirement financial adequacy.

The difference may partly reflect the fact that two different cohorts are living in different economic eras. The baby boomers may have lived in less favourable social economic political and technological conditions and therefore they are already satisfied 
with the progress they experience. On the other hand, Millennials live in the era of plenty and high technology. Their aspiration may be much higher than the baby boomers.

In Indonesia, data from the pilot study (Moeis, 2018) reveals that desired retirement income ratio among workers (future retirees) is relatively high in each group of desired retirement age. Retirement ratio is the ratio between retirement income and the last income when working. Hereafter, retirement income refers to retirement income ratio.

It should be noted that out of 2,020 workers in the sample, Table 3 is based only on 1,260 workers, who can provide information on their desired retirement income. The fact that $37.62 \%$ could not provide their desired retirement income may indicate uncertainty in their future or simply ignorance of the future, revealing pessimism of the workers on their future retirement income, strengthening the global conclusion based on HSBC data.

Table 3. Workers' desired retirement age and desired retirement income ratio

\begin{tabular}{lrrc}
\hline $\begin{array}{l}\text { Desired } \\
\text { retirement age }\end{array}$ & Number & Percentage & $\begin{array}{c}\text { Desired } \\
\text { retirement income* }\end{array}$ \\
\hline$<40$ & 8 & 1.09 & 141.88 \\
$41-50$ & 81 & 6.32 & 95.43 \\
$51-60$ & 682 & 61.30 & 83.23 \\
$61-70$ & 383 & 25.18 & 81.37 \\
$70+$ & 106 & 5.75 & 97.31 \\
\hline Total & 1,260 & 100.00 & 85.01 \\
\hline
\end{tabular}

Note: ${ }^{*}$ Calculated based on data from the pilot study.

The desired retirement incomes by desired age of retirement group are at least $80 \%$ of their final income (Table 3). This desired retirement income is much higher than $75 \%-80 \%$, the consensus among financial analysts, as described in Brady (2010) to maintain previous standard of living. The desired income is even much higher than $60 \%$ from Brady's simulation of financial adequacy with data in the US. However, the desired income in the pilot study is still lower than the $100 \%$ among poor communities in the US in Brady's simulation. It should be noted that the pilot data reflects Indonesia's future older persons who are more urban and educated.

The high desired retirement income among workers may imply that they currently perceive that they have low income and they want to raise their standard of living when they are old. Another possibility is that the current workers foresee an uncertain future and/or anticipate high health costs in their old age.

The high desired retirement income among workers is in contrast to the low actual retirement income among the retirees. Table 4 shows that the largest retirement income is only $61.25 \%$ among those who retired at $61-70$. None of the income is higher than $70.0 \%$, mentioned by Brady (2010) as the minimum retirement income to maintain their standard of living. Except the outlier, the highest retirement income is seen among 
Table 4. Actual retirement income by actual retirement age and current age

\begin{tabular}{lrc}
\hline & $\begin{array}{c}\text { Actual retirement } \\
\text { income }\end{array}$ & $\begin{array}{c}\text { Number of } \\
\text { observations }\end{array}$ \\
\hline $\begin{array}{lr}\text { Actual retirement age } \\
<40\end{array}$ & 800.00 & 1 \\
$41-50$ & 37.50 & 5 \\
$51-60$ & 34.41 & 17 \\
$61-70$ & 62.25 & 4 \\
Current Age & & \\
$<40$ & 800.00 & 1 \\
$41-50$ & 43.75 & 4 \\
$51-60$ & 53.13 & 8 \\
$61-70$ & 35.17 & 14 \\
\hline Note: $\quad$ Retirement income refers to ratio between retirement income and final \\
$\quad$ income before retirement. \\
Source: Calculated on data from Moeis (2018).
\end{tabular}

those who were aged 51-60, at 53.1\%. At age 51-60, people may reach the peak of their career. It may show an inverted-U curve relationship between income and age, as discussed in López Ulloa et al. (2013).

In other words, though the national data set indicates a relatively high percentage of perceived financial adequacy (at $78.5 \%$ in 2015), they may not be able to maintain their previous standard of living and may even live under a subsistent level. This is supporting the national data set mentioned earlier, which shows that some provinces have low indicators of objective income but high perceived financial adequacy. They may have simply accepted their current financial condition.

Furthermore, there is a positive correlation between actual retirement age and actual retirement income among retirees. Higher retirement age may mean more time to accumulate savings.

However, Table 4 shows an outlier. As mentioned earlier, a respondent, age below 40 years have already retired. This young retiree received an outstanding retirement income $-800 \%$ of the final income. There are two possibilities for this outlier. First, this person may have a very low income. Second, this person is confident that he/she can accumulate a lot of money in the remaining years of his/her life. This phenomenon is similar to the one found in HSBC (2017) where the Millenials desire to retire at younger ages than the generation $X$ and baby boomers. Though this is an outlier, it warrants a further study on young persons dreaming to retire young and rich.

\section{Concluding Remarks}

This paper concludes that older persons in Indonesia have to depend on their own as long as they can and on their family when they cannot sufficiently support themselves financially. However, some provinces have low indicators of objective income though 
having higher percentage of older persons perceiving financial adequacy. These persons may have accepted their financial condition. On average there is a positive association at the provincial level between objective indicator of income and PFA.

Furthermore, older persons may not have sufficient retirement income to maintain their standard of living before retirement and may even live under subsistence level. In contrast, working younger persons (future retirees) may have much higher desired retirement income, being higher than $70-80 \%$ in the financial analysts' consensus. The first possibility is that these persons may face future uncertainty and high cost of living during retirement. The second possibility is that their income during working time is not high and therefore they may want to have a higher standard of living upon retiring.

This paper also concludes that PFA does not seem to be associated with whether the older person is working or not, but on the intensity of work (number of hours/per week) and flexibility of the job (in informal sector and/or in trade). This may indicate that older persons rely a lot on working for their PFA. Furthermore, good health and decent living environment may matter in improving PFA. Social assistance may have helped the lowest income group, but it may not have helped them to escape from poverty and may have increased the likelihood that the lowest income group does not perceive having financial adequacy at old age.

It is also possible that people may want to have later retirement ages, as their retirement income may not be adequate and there may not be sufficient transfer during their old age. They may not believe that there will be a generous pension system that they can rely on when they are old. They may also be doubtful that the family and community are reliable sources of financial support when they are old. Future uncertainty and rising health costs may also make them desire to work longer.

Raising the retirement age will therefore reduce the responsibility of the state, communities, and families to support and take care of the older persons. At the same time, raising retirement age will raise tax revenue for the state budget. As an alternative, the retirement age can be made optional, where people can have the right to decide when to retire. They may continue to work as long as they are still capable in terms of health and skill. At the same time, promotion and demotion should not be based on chronological age. People can be demoted or fired when they are not productive before the retirement age. Policies need to be performed to raise objective indicators of income, promote health or delay the deterioration of health, and improve the living environment so that people can work longer and better. Social assistance should also be continued.

\section{References}

Arifin, E.N., \& Ananta, A. (2009). Employment of older persons: Diversity across nations and subnations in Southeast Asia. In E.N. Arifin \& A. Ananta (Eds.), Older persons in Southeast Asia: An emerging asset. Institute of Southeast Asian Studies.

Ayllion, S., \& Fusco, A. (2017). Are income poverty and perception of financial difficulties dynamically interrelated? Journal of Economic Psychology, 61(C), 103-114. https://doi. org/10.1016/j.joep.2017.03.008

Badan Pusat Statistik. (2015). Population of Indonesia: Result of the 2015 Intercensal Population Census. 
Badan Pusat Statistik. (2016). Statistik penduduk lanjut usia 2015.

Cheng, G.H.L., \& Angelique Chan, A.W.M. (2018). To work or not to work: Retirement and health among older Singaporeans (Research Brief no. 5), Center for Ageing Research and Education, Duke-NUS Medical School.

Brady, P.J. (2010). Measuring retirement resources adequacy. Journal of Pension Economics \& Finance, 9(2), 235-262. https://doi.org/10.1017/S1474747208003806

Feng, Q., Yeung, W.-J.J., Wang, Z., \& Zeng, Y. (2019). Age of retirement and human capital in an aging China, 2015-2050. European Journal of Population, 35(1): 29-62. https://doi. org/10.1007/s10680-018-9467-3

Gildner, T.E., Liebert, M.A., Capistrant, B.D., D’Este, C., Snodgrass, J.J., \& Kowal, P. (2016). Perceived income adequacy and well-being among older adults in six low- and middleincome countries. Journals of Gerontology. Series B: Psychological Sciences and Social Sciences, 74(3), 516-525. https://doi.org/10.1093/geronb/gbw145

Grable, J.E., Cupples, S., Fernatt, F., \& Anderson, N. (2013). Evaluating the link between perceived income adequacy and financial satisfaction: A resource deficit hypothesis approach. Social Indicators Research, 114(3), 1109-1124. https://doi.org/10.1007/s11205-012-0192-8

Hanna, S.D., Zhang,L., \& Kim, K.T. (2017). Do worker expectations of never retiring indicate a preference or an inability to plan? Journal of Financial Counselling and Planning, 28(2), 268284. https://doi.org/10.1891/1052-3073.28.2.268

Harding, R. (2018, September 4). Japan's Shinzo Abe vows to raise retirement age. Financial Times.

HSBC. (2017). The future of retirement: Shifting sands. Global Report.

Li, J., Montalto, C.P., \& Geistfeld, L.V. (1996). Determinants of financial adequacy for retirement. Financial Counseling and Planning, 7, 39-48.

Litwin, H., \& Sapir, E.V. (2009). Perceived income adequacy among older adults in 12 countries: Findings from the survey of health, ageing, and retirement in Europe. Gerontologist, 49(3), 397-406. https://doi.org/10.1093/geront/gnp036

Moeis, A.I.A. (2018). An inquiry into a just and financially sustainable pension system: An illustration with Indonesia's data (Doctoral dissertation, Faculty of Economics and Business, Universitas Indonesia).

Rappaport, A., \& Bajtelsmit, V. (2019). The present and future of retirement income adequacy: The role of employer retirement plan. Benefit Quarterly, Second quarter. https://www.ifebp. org/inforequest/ifebp/0201408.pdf

Reyers, M. (2018). Perceptions of retirement adequacy: Evidence from South Africa. Journal of Financial Counseling and Planning, 29(2), 343-356. https://doi.org/10.1891/10523073.29.2.343

Sanjaya, B. (2016). Persepsi kecukupan keuangan lansia di Indonesia. Analisis Supas 2015. [Perceived financial adequacy among older people in Indonesia. 2015 Supas Analysis]. Thesis for Master Programme in Population and Labour Studies, Universitas Indonesia.

Sewdas, R., de Wind, A., van der Zwaan, L.G.L., van der Borg, W.E., Steenbeek, R., van der Beek, A.J., \& Boot, C.R.L. (2017). Why older workers work beyond the retirement age: A qualitative study. BMC Public Health, 17, Article 672. https://doi.org/10.1186/s12889-017-4675-z

Stoller, M.A., \& Stoller, E.P. (2003). Perceived income adequacy among elderly retirees. Journal of Applied Gerontology, 22(2), 230-251. https://doi.org/10.1177\%2F0733464803022002004

López Ulloa, B.F., Moller, V., \& Sousa-Poza, A. (2013). How does subjective well-being evolve with age? A literature review. Population Ageing, 6, 227-246. https://doi.org/10.1007/s12062013-9085-0

VanDerhei, J., \& Copeland, C. (2011). The impact of deferring retirement age on retirement income adequacy (EBRI Issue Brief, no. 358). https://www.ebri.org/crawler/view/the-impactof-deferring-retirement-age-on-retirement-income-adequacy-4831 
Works, R. (2015). The satisfaction of retirement. Monthly Labor Review, November. https://www. bls.gov/opub/mlr/2015/beyond-bls/the-satisfaction-of-retirement.htm

Žiković, I.T. (2020). Poverty, the worst form of violence: Perceived income adequacy among Croatian citizens. Economic Research-Ekonomska Istraživanja, 33(1): 712-730. https://doi. org/10.1080/1331677X.2020.1720769 